Int. J. Environ. Res. Public Health 2007, 4(3), 195-202

International Journal of

Environmental Research and Public Health

ISSN 1661-7827

www.ijerph.org

(c) 2007 by MDPI

\title{
Fluoro-edenite Fibers Induce Expression of Hsp70 and Inflammatory Response
}

\author{
Venera Cardile ${ }^{1 *}$, Laura Lombardo ${ }^{1}$, Elena Belluso ${ }^{2}$, Annamaria Panico ${ }^{3}$, Marcella Renis ${ }^{4}$, Antonio Gianfagna ${ }^{5}$, and \\ Michael Balazy ${ }^{6^{*}}$ \\ ${ }^{1}$ Department of Physiological Sciences, University of Catania, V.le A. Doria 6, 95125 Catania, Italy \\ ${ }^{2}$ Department of Mineralogical and Petrological Sciences, University of Turin, Turin, Italy, CNR IGG-Sezione I Torino, Italy \\ ${ }^{3}$ Department of Pharmaceutical Sciences, University of Catania, Catania, Italy \\ ${ }^{4}$ Department Biological Chemistry, Clinical Biochemistry and Molecular Biology, University of Catania, Italy \\ ${ }^{5}$ Department of Earth Sciences, University "La Sapienza”, Rome, Italy \\ ${ }^{6}$ Department of Pathology, New York Medical College, Valhalla, NY 10595, USA \\ *Correspondence to Dr. Venera Cardile; E-mail: Cardile@unict.it or Dr. Michael Balazy; E-mail: Michael_Balazy@nymc.edu
}

Received: 01 June 2007 / Accepted: 06 September 2007 / Published: 30 September 2007

\begin{abstract}
Many asbestos-like mineral fibers have been detected in the air of mountainous and volcanic areas of Italy and other parts of the world. These fibers have been suspected to be the cause of increased incidences of lung cancer and other lung diseases in these areas. However, the mechanisms of the cellular response and defense following exposure to these microscopic fibers have not been characterized. We continue to study these mechanisms to be able to propose preventive strategies in large populations. The objective of the present study was to determine comparatively biological responses of mesothelial Met-5A and monocyte-macrophage J774 cells following exposure to two types of fluoro-edenite fibers having low and high iron content (labeled 19 and 27, respectively) obtained from Biancavilla (Sicily, Italy). The reference fiber was a non-iron fibrous tremolite from Val di Susa (Piemonte, Italy). The cells were treated with 5, 50, and $100 \mu \mathrm{g}$ of fibrous matter per $1 \mathrm{ml}$ for $72 \mathrm{hr}$. We identified several key mechanisms by which cells responded and counteracted the injury induced by these fibers. The fibers caused induction of the heat shock protein 70 (Hsp70), stimulated formation of reactive oxygen species (detected by using DCFH-DA as a fluorescent probe) and $\mathrm{NO}^{\circ}$ (measured as nitrite). Exposure of cells to the fibers induced lactate dehydrogenase activity and decreased viability. The fluoro-endenite type $\mathbf{2 7}$ was the most potent fiber tested, which indicated that iron and possibly manganese contribute significantly to this fiber toxicity. The J774 cells were more sensitive to fluoro-edenite than Met-5A cells suggesting that the primary site of the fiberinduced inflammatory response could be the macrophage rather than the pulmonary epithelium. Fluoro-edenite produces more biological alterations with respect to non-iron tremolite. Hsp70 and free radicals could be important factors in the context of mineral fiber-induced acute lung injury leading possibly to mutagenic effects. We anticipate that pharmacological blockade of the fiber-dependent cellular responses could in long term offer preventive approach to combat lung diseases induced by these fibers.
\end{abstract}

Keywords: asbestos-like fibers; cell cultures; Hsp70; lung disease; oxidative stress; stress protein.

\section{List of Abbreviations}

DMEM Dulbecco's modified Eagle's medium

FBS Foetal bovine serum 


$\begin{array}{ll}\text { Hsp 70 } & \text { Heat shock protein 70 kDalton } \\ \text { DCFH-DA } & \text { 2'7'-dichlorodihydrofluorescein diacetate } \\ \text { DMSO } & \text { Dimethylsulphoxide } \\ \text { LDH } & \text { Lactate dehydrogenase } \\ \text { MTT } & \text { 3-(4,5-dimethylthiazol-2-yl)-2,5-diphenyl tetrazolium bromide test } \\ \text { NF-kB } & \text { Nuclear factor kappa B } \\ \text { PBS } & \text { Phosphate buffered saline } \\ \text { ROS, RNS } & \text { Reactive oxygen/nitrogen species } \\ \text { SEM-EDS } & \text { Scanning electron microscopy-energy dispersive spectrometer } \\ \text { TEM-EDS } & \text { Transmission electronic microscopy-energy dispersive spectrometer }\end{array}$

\section{Introduction}

The objectives of our study were (1) to determine in vitro the effects of two types of asbestiform fibers: tremolite and fluoro-edenite, (2) investigate the potential stress dependence of the Hsp70 response, and (3) to evaluate the possible use of the Hsp70 over-expression as a biomarker of fibrous minerals exposure. One of the most effective protein folding systems is Hsp70, which causes folding of a wide variety of protein substrates [1]. Two isoforms of Hsp70 exist in the cytoplasm of mammal cells: a $73-\mathrm{kDa}$ form that is constitutively expressed and a 72-kDa, stress-inducible form (Hsp70). Recent studies also identified an extracellular form of Hsp70, which may play a key role in the induction of the cellular immune response $[2,3]$.

Expression of the inducible Hsp70 is activated by a large variety of stress conditions, toxins and factors, so that Hsp70 induction has been considered as a nonspecific response [4] that offers protection from such conditions [5]. Moreover, based on comparison of several in vitro studies, Wong and Wispe have suggested that at least in pulmonary cells, the pattern of stress protein expression might depend more closely on the type of stimulus [6]. Pulmonary tissue is unique with regard to the stress response because it represents the main target for environmental toxins and expresses a higher basal level of inducible Hsp70 than other tissues [4]. Because inhalation of asbestos particles induces many pulmonary diseases, the study of Hsp70s may contribute greatly to this field of research; Hsp expression can be interpreted as an early, sensitive bio-indicator of stressed cells and may help to increase resistance toward adverse situations.

Fluoro-edenite is a newly discovered fibrous mineral, the presence of which has been correlated with the incidence of mesothelioma that develops among residents in Biancavilla (Catania), a town in eastern Sicily located in the Etna volcanic area [7,8]. In this study, we used two types of amphibolic fluoro-edenite, 19 and 27, that have low and high iron content, respectively. Met-5A, human non-malignant transformed mesothelial cells, which contributed to studies on pleural pathology [9], and J774 cells, a mouse monocyte-macrophage cell line [10], were used to test the effects of these fibers on cytotoxicity and viability. The effects of fluoro-edenite were compared with those of tremolite, a non-iron fibrous mineral and a member of the calcic amphibole group of asbestos, originating from construction activities in the Upper Susa Valley (Piedmont, Italy) from the surface rocks undergoing natural ground erosion. A recent report suggested tremolite may induce pulmonary pathology [11].

\section{Materials and Methods}

\section{Preparation of Cell Cultures}

Met-5A mesothelial cells (kindly provided by Prof. G. Biagini, Istituto di Morfologia Umana NormaleIstologia, Università Politecnica delle Marche) were grown in RPMI medium (Sigma, Milan, Italy) supplemented with $10 \%$ foetal bovine serum (FBS), $1 \%$ non-essential amino acids, $2.0 \mathrm{mM}$ L-glutamine, and antibiotics, and incubated at $37^{\circ} \mathrm{C}$ with $5 \% \mathrm{CO}_{2} / 95 \%$ air. The cells were routinely split each week and used between the $4^{\text {th }}$ and $5^{\text {th }}$ passages. Prior to experiments, cells from confluent cultures were detached using $0.25 \%$ trypsin plus $1 \mathrm{mM}$ EDTA and seeded in complete RPMI medium. J774 cells were obtained from American Type Culture Collection (Rockville, MD). These cells were cultured in Dulbecco's modified Eagle's medium (DMEM) containing 10\% FBS, $4.5 \mathrm{~g} / \mathrm{L}$ glucose, $1 \mathrm{mM}$ sodium pyruvate, $2.0 \mathrm{mM}$ L-glutamine, and antibiotics (Invitrogen, Paisley, UK) and incubated at $37^{\circ} \mathrm{C}$ with $5 \%$ $\mathrm{CO}_{2} / 95 \%$ air. The medium was changed every three days and cell subcultures were prepared every 7-9 days. Prior to experiments, cells were trypsinized, counted by haemocytometer, plated onto 6- or 96-well plates (Costar, Cambridge, MA), and grown in a humidified $5 \% \mathrm{CO}_{2} /$ $95 \%$ air incubator at $37^{\circ} \mathrm{C}$. Tremolite and fluoro-edenite particles were suspended in culture medium and added to the cell cultures by a micro-syringe in amounts corresponding to final concentrations of 5, 50, and 100 $\mu \mathrm{g} / \mathrm{ml}\left(1.06,10.6\right.$, and $\left.21.2 \mu \mathrm{g} / \mathrm{cm}^{2}\right)$. Cells were then incubated for $72 \mathrm{hrs}$.

\section{Preparation and Composition of Asbestos Fibers}

The samples of amphibolic fluoro-edenite fibers were collected in the area of Biancavilla (Sicily), and were subsequently analysed by microanalytical spectroscopic methods (SEM-EDS, TEM-EDS, XRD, FT-IR, Mössbauer, and Raman). Comparison of these samples with the standards of prismatic fluoro-edenite, which 
originated from the same volcanic materials of that area and were previously described [8], revealed identical composition and crystal structure. Typology of some fibers also showed winchitic and richteritic compositions due to the minor differences in chemical composition. We developed a method for enrichment and purification of amphibolic fibers, which removed other components of the rock matrix. A gravimetric sedimentation method was used to concentrate the fine material, exploiting differences in their mineral densities and relevant morphologies. This method allowed us to obtain a fibrous material with $95 \%$ of the amphibolic fibre content. Two fractions of different types of fibrous fluoro-edenite were obtained for use in this study and were labelled as fluoroendenite 19 and fluoro-endenite 27.

The chemical formula of fibre 19 was:

$\left(\mathrm{Na}_{0.256} \mathrm{~K}_{0.164}\right)_{\Sigma 0.420}\left(\mathrm{Ca}_{1.311} \mathrm{Na}_{0.555} \mathrm{Mg}_{0.131}\right)_{\Sigma 1.997}\left({ }^{\mathrm{VI}} \mathrm{Al}_{0.200} \mathrm{Fe}^{3+}{ }_{0}\right.$ $\left.{ }_{.180} \mathrm{Fe}^{2+}{ }_{0.180} \mathrm{Mg}_{4.322} \mathrm{Ti}_{0.060} \mathrm{Mn}_{0.059}\right)_{\Sigma 4.931}\left(\mathrm{Si}_{7.679}{ }^{\mathrm{IV}} \mathrm{Al}_{0.317}\right)_{\Sigma 7.996} \mathrm{O}$ ${ }_{22}\left(\mathrm{~F}_{1.970} \mathrm{Cl}_{0.020}\right)_{\Sigma 1.990}$;

whereas the chemical formula of fluoro-edenite 27 was:

$\left(\mathrm{Na}_{0.307} \mathrm{~K}_{0.157}\right)_{\Sigma 0.464}\left(\mathrm{Ca}_{1.505} \mathrm{Na}_{0.495}\right)_{\Sigma 2.000}\left({ }^{\mathrm{VI}} \mathrm{Al}_{0.104} \mathrm{Fe}^{3+}{ }_{0.333} \mathrm{Fe}^{2+}\right.$ $\left.{ }_{0.162} \mathrm{Mg}_{4.255} \mathrm{Ti}_{0.062} \mathrm{Mn}_{0.063}\right)_{\Sigma 4.980}\left(\mathrm{Si}_{7.520}{ }^{\mathrm{IV}} \mathrm{Al}_{0.480}\right)_{\Sigma 8.000} \mathrm{O}_{22}\left(\mathrm{~F}_{1.970}\right.$ $\left.\mathrm{Cl}_{0.020}\right)_{\Sigma 1.990}$.

These two forms differed in their iron content and the $\mathrm{Fe}^{2+} / \mathrm{Fe}^{3+}$ ratio. Form 27 of fluoro-edenite had about $70 \%$ of $\mathrm{Fe}^{3+}$, whereas form 19 had $50 \% \mathrm{Fe}^{3+}$ and a lower total content of iron than form 27. Both forms contained similar amounts of manganese. The chemical formula of fibrous tremolite obtained from Val di Susa (Piemonte, Italy) was $\mathrm{Ca}_{2}\left(\mathrm{Mg}, \mathrm{Fe}^{2+}\right)_{5}\left[\mathrm{Si}_{8} \mathrm{O}_{22}\right](\mathrm{OH})_{2}$, as determined with microanalytical techniques by Rinaudo et al. [11]. All fibers had an average length and diameter of $30 \mu \mathrm{m}$ and $5 \mu \mathrm{m}$, respectively.

\section{Identification of Hsp70}

The expression of Hsp70 was evaluated by Western blot analysis. Briefly, the untreated and treated cells were washed twice with ice-cold PBS and collected with lysing buffer $(50 \mathrm{mM}$ Tris- $\mathrm{HCl}$ plus $20 \mathrm{mM}$ EDTA and $0.5 \%$

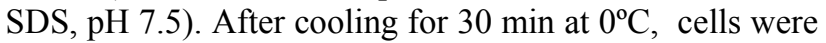
homogenized and centrifuged at $13,000 \times \mathrm{g}$ for $15 \mathrm{~min}$. Twenty micrograms of total protein, present in the supernatant, were loaded on each lane and separated by $10 \%$ Novex Bis-Tris gel electrophoresis (NuPAGE, Invitrogen) according to published methods [12]. Proteins were then transferred to nitrocellulose membranes (Invitrogen) in a wet system. The transfer of proteins was verified by staining the nitrocellulose membranes with Ponceau S and the Novex Bis-Tris gel with Brillant blue R. Membranes were blocked in Trisbuffered saline containing $0.01 \%$ Tween-20 (TBST) and $10 \%$ non-fat dry milk at $4{ }^{\circ} \mathrm{C}$ overnight. Primary mouse anti-Hsp70 (Santa Cruz Biotechnology, Santa Cruz, CA) monoclonal antibody and rabbit polyclonal $\alpha$-tubulin antibody (Sigma, Milan, Italy) were diluted (1:1000) in
TBST and membranes incubated for $2 \mathrm{~h}$ at room temperature. Antibodies were detected with horseradish peroxidase-conjugated secondary antibody using the enhanced chemiluminescence detection Supersignal West Pico Chemiluminescent Substrate (Pierce Chemical Co., Rockford, IL). Bands were measured densitometrically and their relative density calculated based on the density of the $\alpha$-tubulin bands in each sample. Values were expressed as arbitrary densitometric units corresponding to signal intensity.

\section{Analysis of Reactive Oxygen Species}

Reactive free radical species formation was estimated by using DCFH-DA as a fluorescent probe (Molecular Probes, Eugene, OR). DCFH-DA diffuses through the cell membrane and is enzymatically hydrolyzed by intracellular esterases to fluorescent DCFH in the presence of reactive oxygen species (ROS) [13]. The intensity of fluorescence was proportional to the levels of intracellular ROS. Thirty minutes before the end of the treatment time, $5 \mu \mathrm{M}$ DCFH-DA was added to cell cultures (control or treated with various amounts of tremolite or fluoro-edenite). The cells were maintained in a humidified atmosphere $\left(5 \%\right.$ of $\mathrm{CO}_{2}$ and $95 \%$ air) at $37^{\circ} \mathrm{C}$. Dye-loaded cells were washed with PBS and the fluorescence was monitored in scraped and resuspended cells using a luminescence spectrometer (Perkin-Elmer, Monza, Italy). The excitation and emission wavelengths were $475 \mathrm{~nm}$ and $525 \mathrm{~nm}$, respectively.

\section{Analysis of Nitrite and $\mathrm{LDH}$}

Nitrite concentration in the supernatant was quantified by colorimetric assay based on the Griess reaction [14] as described by Ding et al. [15]. Briefly, 0.1 $\mathrm{ml}$ of the supernatant from untreated or treated cultures was mixed with an equal volume of Griess reagent at room temperature for $10 \mathrm{~min}$. The absorbance was measured at $550 \mathrm{~nm}$ in a microplate spectrophotometer reader (Titertek Multiskan, DAS, Italy). Sodium nitrite solutions were used to standardize the assay.

The enzymatic activity of LDH was measured spectrophotometrically in culture media and in the cellular lysates at $340 \mathrm{~nm}$ to detect NADH reduction during the pyruvate-lactate transformation [16]. The untreated control and tremolite or fluoro-edenite treated cells were harvested, washed in PBS, mixed with lysis buffer $(50 \mathrm{mM}$ Tris $\mathrm{HCl}, 20 \mathrm{mM}$ EDTA, 0.5\% SDS, pH 7.4), sonicated, and centrifuged at $10,000 \times \mathrm{g}$ for $15 \mathrm{~min}$. The supernatant was collected and analysed for protein content according to the Bradford procedure [17] and for enzymatic activity. The incubation mixture $(1 \mathrm{ml}$ final volume) for enzymatic analysis contained: $33 \mu \mathrm{l}$ of sample in $48 \mathrm{mM}$ PBS ( $\mathrm{pH} 7.5$ ) with $1 \mathrm{mM}$ pyruvate and $0.2 \mathrm{mM}$ reduced pyridinic coenzyme. Release of LDH was calculated as a percentage of the total amount, considered as the sum of the enzymatic activity present in the cellular lysate and that of the culture medium. 


\section{Determination of Cell Viability}

The MTT proliferation assay is based on the conversion, by mitochondrial dehydrogenases of the substrate containing a tetrazolium ring, into blue formazan, which is detectable by spectrophotometry [18]. The level of blue formazan was used as an index of cell density. Briefly, cell cultures were set up in flat-bottomed $200 \mu 1$ microplates, incubated at $37^{\circ} \mathrm{C}$ in a humidified $5 \%$ $\mathrm{CO}_{2} / 95 \%$ air mixture, and treated with 5, 50, and 100 $\mu \mathrm{g} / \mathrm{ml}$ of fibers for $72 \mathrm{hr}$. Four hours before the end of the culture, $20 \mu \mathrm{l}$ of $0.5 \%$ MTT in PBS was added to each microwell. After incubation with the reagent, the supernatant was removed and replaced with $100 \mu \mathrm{l}$ of dimethylsulfoxide (DMSO). The optical density of each sample was measured with a microplate spectrophotometer reader (Titertek Multiskan, DAS, Italy) at $550 \mathrm{~nm}$. For each sample three replicates were performed.

\section{Results}

Figures $1 \mathrm{a}$ and $1 \mathrm{~b}$ show dose-dependent changes of the Hsp70 levels following treatment with the asbestiform particles of J774 and Met-5A cells, respectively. Both 19 and 27 forms of fluoro-endenite were remarkably potent stimuli of Hsp70, and both with similar potency. Fluoroedenite, at concentrations as low as $5 \mu \mathrm{g} / \mathrm{ml}$, caused induction of Hsp70 protein in both cell lines following exposure for $72 \mathrm{hrs}$. Interestingly, J774 cells were more sensitive to these particles in terms of Hsp70 induction than Met-5A cells. In addition, the increase of Hsp70 was more sustained in fluoro-edenite-treated J774 cells. On the other hand, tremolite was less effective than fluoroedenite in eliciting of the concentration-dependent increase of Hsp70 in both cell lines. Treatment of cells with tremolite at $100 \mu \mathrm{g} / \mathrm{ml}$ had a similar effect as treatment with fluoro-edenite at $5 \mu \mathrm{g} / \mathrm{ml}$.
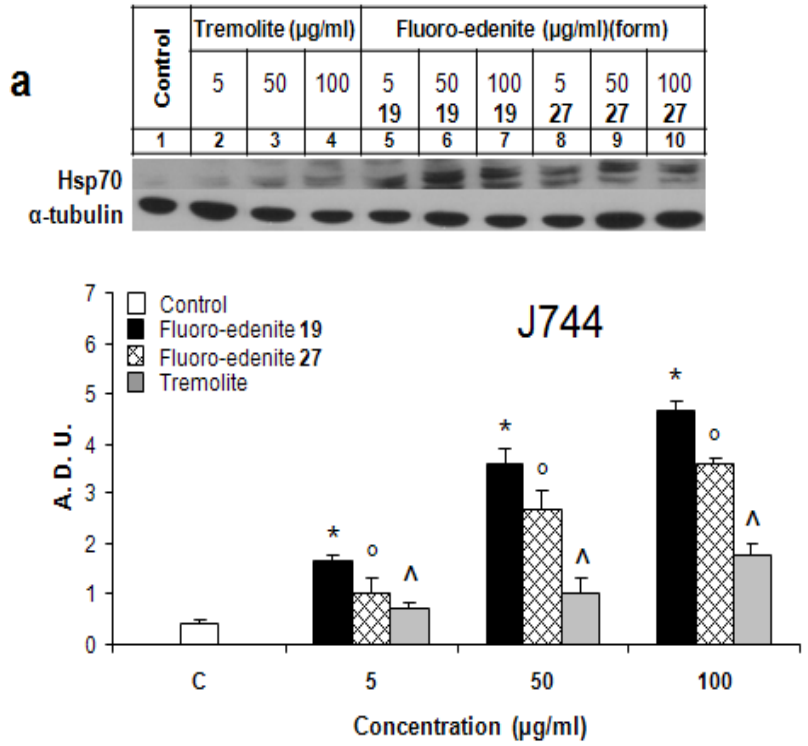

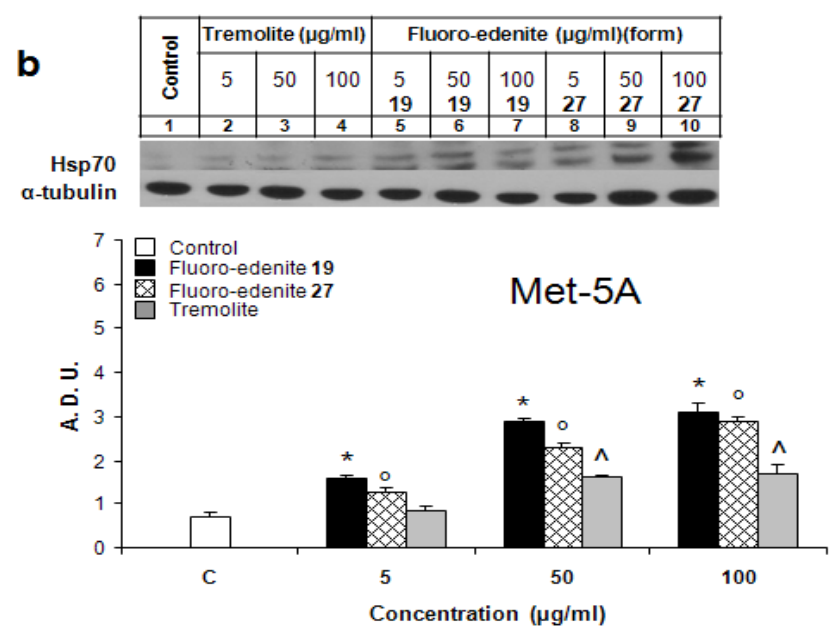

Figure 1: Hsp70 levels in J774 (a) and Met-5A (b) cells evaluated by Western blot analysis. Bands were measured densitometrically and the relative density was calculated based on the density of $\alpha$-tubulin bands in each sample. The values were expressed as arbitrary densitometric units (A.D.U.) obtained by analysis of the autoradiograms with ID image analysis software. The bars represent the mean \pm SEM of three experiments performed in triplicate. All values with $\mathrm{P}<0.01$ were considered significantly different. $* \circ \wedge$ denote significant differences of values compared to untreated control. Numbers 19 and 27 refer to two chemically distinct forms of fluoro-endenite.
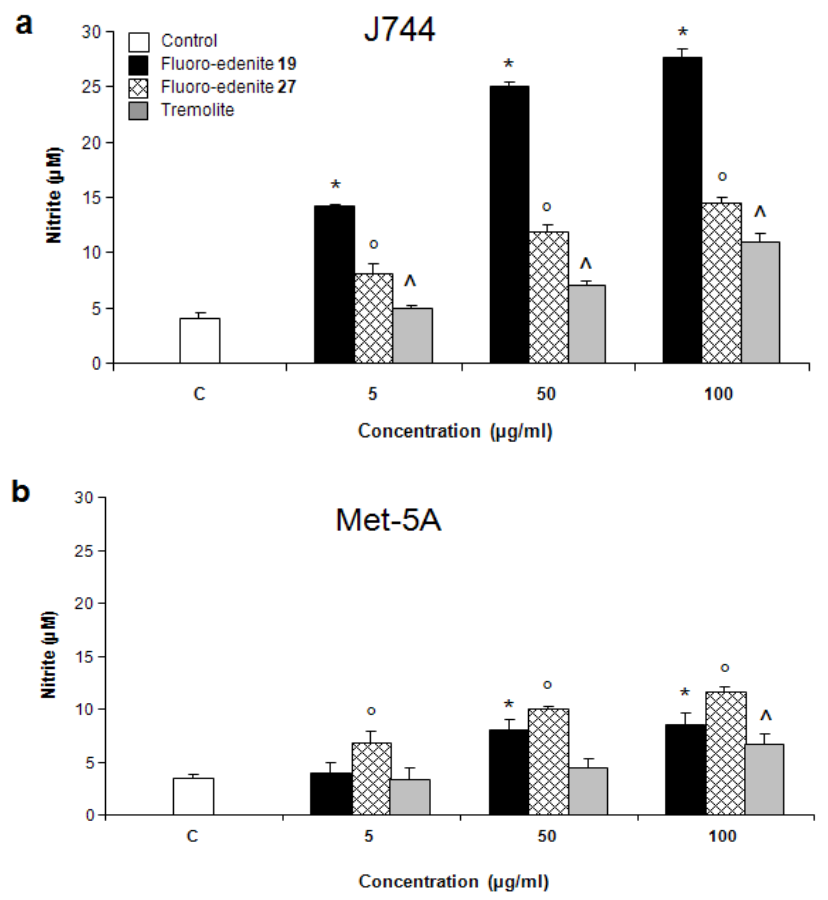

Figure 2: Release of nitrite from J774 (a) and Met-5A (b) cells quantified by colorimetric assay in the culture media. The values, expressed as $\mathrm{nM} / 10^{6}$ cells, are the mean \pm SEM of three experiments performed in triplicate. All values with $\mathrm{P}<0.01$ were considered significantly different and labelled by these symbols $* \circ \wedge$. 
The levels of nitrite (Figures $2 \mathrm{a}$ and $2 \mathrm{~b}$ ) also significantly increased in a concentration-dependent manner in both Met-5A and J774 cells. Treatment of J774 cells with fluoro-edenite, and, in particular, its low iron form $\mathbf{1 9}$ had a remarkably strong effect on NO formation as compared to Met-5A cells. A similar trend was observed with ROS formation, which was examined using a fluorescent probe (Figures $3 \mathrm{a}$ and $3 \mathrm{~b}$ ). Fluoro-edenite form 27 (high iron content) at $5 \mu \mathrm{g} / \mathrm{ml}$ had a strong stimulatory effect on ROS generation in $\mathrm{J} 774$ cells, in contrast to Met-5A cells, which were stimulated by all three forms of the particles. Treatment of cells with fluoro-edenite also stimulated LDH release, which is a marker of necrotic cell death, and an index of cell membrane breakdown (Figures $4 \mathrm{a}$ and $4 \mathrm{~b}$ ). The MTT assay indicated that the viability of Met-5A and J774 cells decreased after treatment with fluoro-edenites and tremolite (Figures 5a and 5b). A significant decrease of cell viability can be seen following exposure to fluoroedenite at $5 \mu \mathrm{g} / \mathrm{ml}$. At this concentration, tremolite was inactive. At higher concentrations, fluoro-edenite $\mathbf{1 9}$ was more potent than the other particles. In summary, our data indicate that these fibers had profound effects on cells and induced several pathways of the inflammatory response.
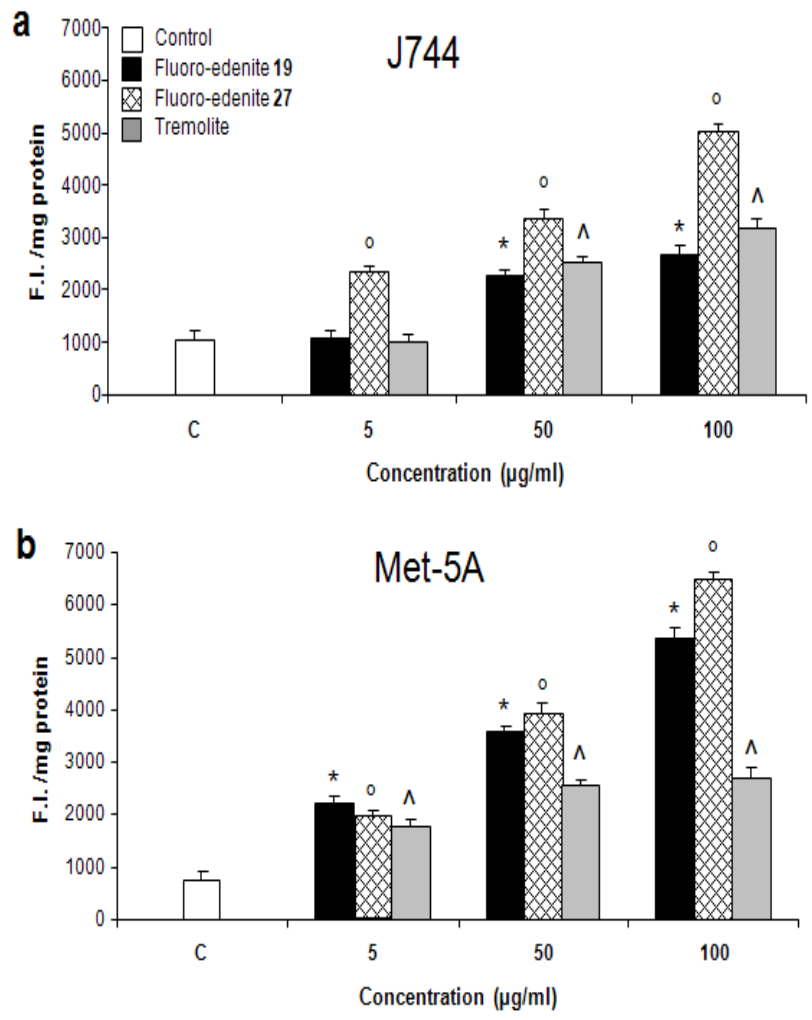

Figure 3: Detection of ROS formation in J774 (a) and Met-5A (b) cells measured by a fluorescence assay. The values, expressed as fluorescence intensity units (F.I.)/mg of proteins, are the mean \pm SEM of three experiments performed in triplicate. All values with $\mathrm{P}<0.01$ were considered significantly different. ${ }^{*} \wedge \wedge$ denotes significant differences versus untreated control.
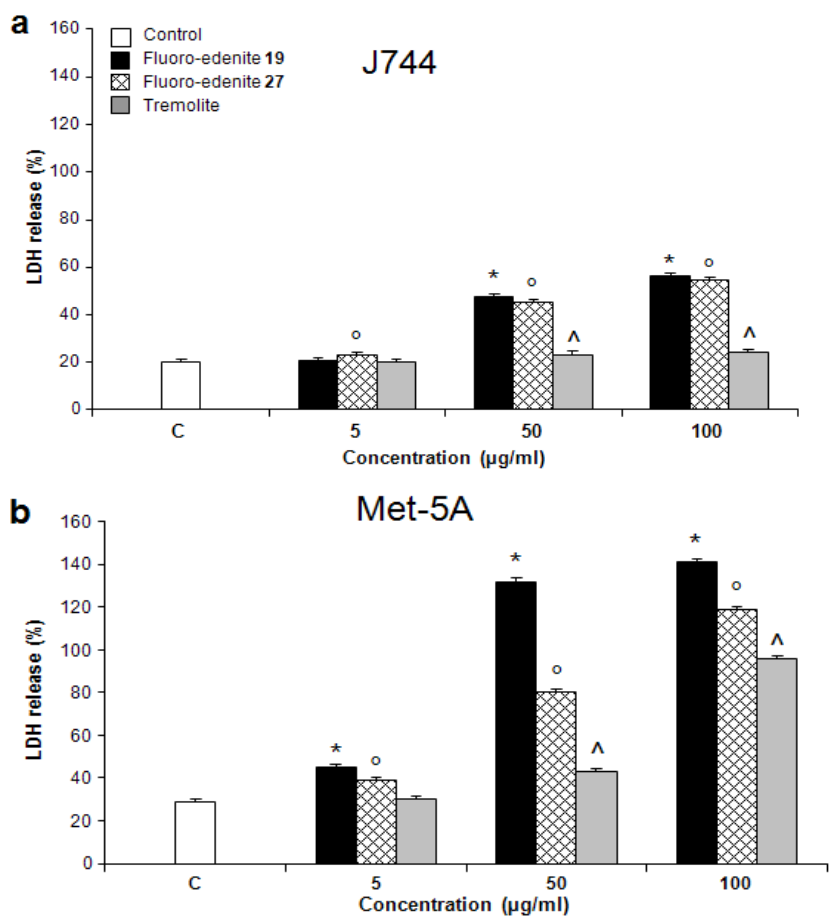

Figure 4: Detection of lactate dehydrogenase (LDH) release from J774 (a) and Met-5A (b) cells expressed as percentage of LDH released into the culture media with respect to total $\mathrm{LDH}$. The values are the mean $\pm \mathrm{SEM}$ of three experiments performed in triplicate. All values with $\mathrm{P}<0.01$ were considered significantly different. The symbols ${ }^{*} \wedge \wedge$ represent significantly different values versus untreated control.
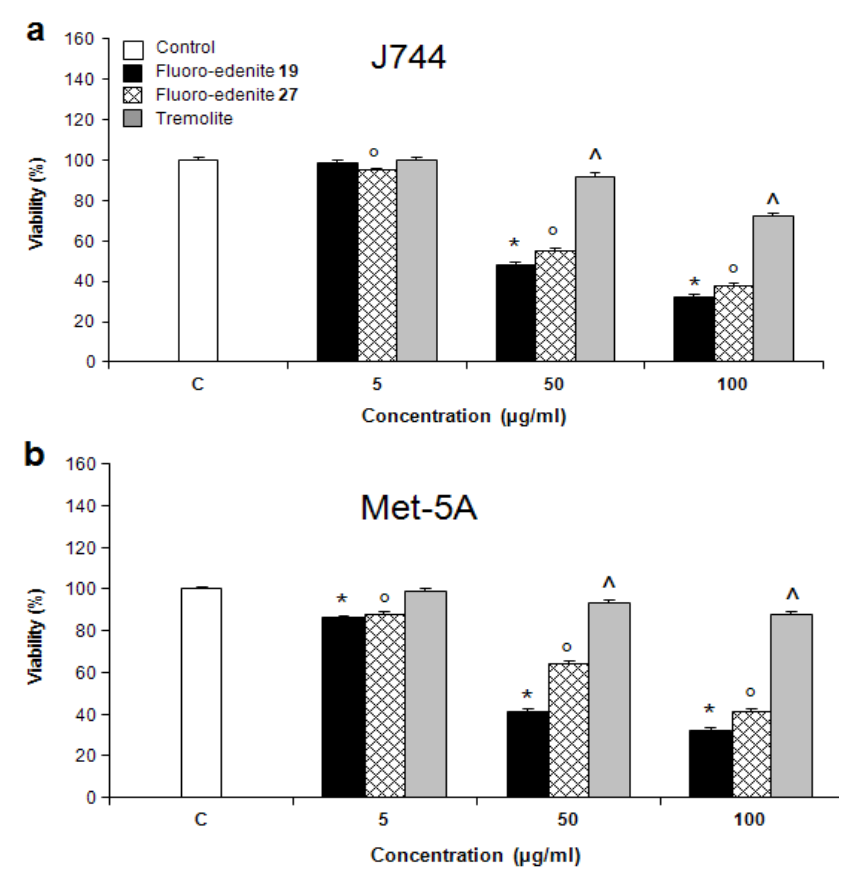

Figure 5: Viability of J774 (a) and Met-5A (b) cells measured with the MTT assay following exposure to mineral fibers. The values of optical density measured at $550 \mathrm{~nm}$ are reported as percentage with respect to the optical density registered for untreated control, the latter considered as $100 \%$ of cell viability. The values are the mean \pm SEM of three experiments 


\section{Discussion}

Fibrous minerals are comprised of approximately 500 distinct species with new species being discovered almost every year. Pollution of air by mineral fibers, which are not considered to be asbestos, such as serpentine and amphiboles, results from both natural and human activities, and has become more frequent in Italy, in the Alps, and near the Sicilian volcano, Etna. Various physicochemical properties of these fibers, such as size, chemical structure, surface charge, the ability to generate reactive oxygen species, and bio-persistence contribute to their potential to induce diseases such as lung cancer, asbestosis, and mesothelioma [19-22].

This study aimed to profile biological responses of J774 and Met-5A cells following exposure to three forms of non-asbestos fibers, and to determine whether these responses were modulated by iron content within some of these fibers. We anticipate that understanding of how cells respond to the microscopic fibers might be helpful to design preventive approaches to protect large populations from consequences of exposure to the airborne mineral particles. This may have important implications for therapeutic strategies to counter fiber-induced lung disease. Our results suggest that both forms of fluoroedenite showed a unique profile of signaling pathway activation. Our experiments demonstrate that both forms of fluoro-edenite were more potent than tremolite at inducing Hsp70, generating reactive oxygen species and nitrite, and decreasing cell viability. The J774 cells were more sensitive to fluoro-edenite in terms of nitrite biosynthesis than Met-5A cells. This suggests that the primary site of the fiber-induced inflammatory response could be on the macrophage rather than the pulmonary epithelium.

We observed that the cells generated both ROS and RNS as an early response to the fluoro-edenite fibers. High-iron fibers 27 were more potent than low-iron fibers 19 in stimulating ROS formation in both mesothelial and macrophage cells. We infer that fibers catalyzed many reactions that resulted in generation of ROS such as the superoxide anion $\left(\mathrm{O}_{2}{ }^{--}\right)$, the hydroxyl radical $\left(\mathrm{HO}^{\circ}\right)$, and the peroxyl radical $\left(\mathrm{HOO}^{\circ}\right)$ that were detected by the fluorescence assay. Redox active iron on the surface or mobilized from phagocytized fibers has the potential to catalyze the formation of ROS via Fenton chemistry. These ROS are likely to stimulate peroxidation of many critical macromolecules, including proteins, nucleic acids, and cell membrane lipids, which may result in cellular dysfunction, cytotoxicity, and possibly malignant transformations [23-26].

While the ability of $\mathrm{NO}^{\bullet}$ to modulate iron metabolism, via activation of iron regulatory proteins is well known [27], data concerning the effect of iron on the regulation of NOS are conflicting, both in vitro and in vivo. Previous study reported that in the J774 murine macrophage cell line, interferon- $\gamma /$ LPS-induced NOS activity was decreased by the presence of iron in the medium, and increased by the incubation with iron chelator, desferroxamine [28]. Crocidolite asbestos fibers
(27\% iron by weight) inhibit NO synthesis in murine macrophages [29]. Our own data are consistent with those observations. The low iron fibers 19 were much more potent inducers of NOS in J744 cells than high iron fibers 27. $\mathrm{NO}^{\bullet}$ adds to the complexity of the reactive substances generated by the fibers because of ancillary reactions such as $\mathrm{NO}^{\bullet}$ plus $\mathrm{O}_{2}^{--}$which generates peroxynitrite, a precursor of nitrogen dioxide $\left({ }^{\circ} \mathrm{NO}_{2}\right)$. Both these substances are potent inducers of protein (tyrosine, thiols) and lipid nitration [30].

Generation of the reactive radical species creates an environment of oxidative stress and stimulates the expression of a number of genes, products of which may be involved in mediating responses from the oxidative injury. Our results demonstrate that the fibers increased expression of Hsp70 protein levels in a concentrationdependent manner. The non-iron fibers of tremolite were much less active, suggesting that the iron and, possibly, also, the manganese content, in the fluoro-edenite fibers may be important in Hsp70 expression and could be mediated by the free radicals.

Fluoro-edenite in both high and low iron forms generated a stronger biological response than tremolite, as reflected by the higher increases of Hsp70, nitrite, and cytotoxicity. Heat shock proteins have been known to be induced by a wide variety of non-thermal conditions and pharmacological substances, conferring protection against non-thermal cytotoxic stimuli $[2,4,31]$. Previous studies have demonstrated that induction of a stress response protects cells against endotoxin-mediated apoptosis [32] and nitric oxide- [31] peroxynitrite- [33], and hydrogen peroxide-induced damage [34]. While new functions continue to be discovered, stress proteins are generally thought to maintain cellular homeostasis by acting as molecular chaperones, facilitating the proper folding and assembly of nascent polypeptides, as well as assisting in the refolding and stabilization of damaged peptides [35]. Hsp70 expression has been well described and is the most highly induced stress protein in both whole lung and in specific lung cell cultures from a variety of species, as well as in response to a variety of stress conditions [36]. More recent studies have reported that stress proteins, particularly Hsp 70, are highly immunogenic and have the capacity to mediate the induction of peptide-specific immunity [37]. Collectively, these observations suggest that stress proteins are likely candidates for endogenous signaling molecules in response to stress [37]. Finally, extracellular Hsp70 (increased serum levels) is evident in a variety of clinical scenarios associated with physiological stress [38].

We observed that increased expression of Hsp70 protein correlated with ROS/RNS levels in fluoro-edenitetreated cells containing high and low iron levels. Thus, it is possible to hypothesize that extracellular Hsp70 may serve a cytoprotective role at lower concentrations in response to exposure to mineral fibers in acute lung injury, but once a certain critical threshold is attained, it may potentiate the inflammatory response, subsequently resulting in significant autoinjury to the host [37]. 
Acknowledgment: This work was supported by grants from the project of Ministero Istruzione Università Ricerca (MIUR) PRIN 2004, National Institutes of Health, Bethesda, MD, USA, and Philip Morris USA, Inc.

\section{References}

1. Wegele, H.; Muller, L.; Buchner, J.: Hsp70 and Hsp90--a relay team for protein folding. Rev. Physiol Biochem. Pharmacol., 2004, 151, 1-44.

2. Milani, V.; Noessner, E.; Ghose, S.; Kuppner, M.; Ahrens, B.; Scharner, A.; Gastpar, R.; Issels, R. D.: Heat shock protein 70 : role in antigen presentation and immune stimulation. Int. J. Hyperthermia, 2002, 18, 563-575.

3. Multhoff, G.: Activation of natural killer cells by heat shock protein 70. Int. J. Hyperthermia, 2002, 18, 576-585.

4. Wirth, D.; Christians, E.; Munaut, C.; Dessy, C.; Foidart, J. M.; Gustin, P.: Differential heat shock gene hsp70-1 response to toxicants revealed by in vivo study of lungs in transgenic mice. Cell Stress. Chaperones, 2002, 7, 387-395.

5. Croute, F.; Beau, B.; Arrabit, C.; Gaubin, Y.; Delmas, F.; Murat, J. C.; Soleilhavoup, J. P.: Pattern of stress protein expression in human lung cell-line A549 after short- or long-term exposure to cadmium. Environ. Health Perspect., 2000, 108, 55-60.

6. Wong, H. R.; Wispe, J. R.: The stress response and the lung. Am. J. Physiol, 1997, 273, L1-L9.

7. Paoletti, L.; Batisti, D.; Bruno, C.; Di Paola, M.; Gianfagna, A.; Mastrantonio, M.; Nesti, M.; Comba, P.: Unusually high incidence of malignant pleural mesothelioma in a town of eastern Sicily: an epidemiological and environmental study. Arch. Environ. Health, 2000, 55, 392-398.

8. Comba, P.; Gianfagna, A.; Paoletti, L.: Pleural mesothelioma cases in Biancavilla are related to a new fluoro-edenite fibrous amphibole. Arch. Environ. Health, 2003, 58, 229-232.

9. Pelin, K.; Hirvonen, A.; Taavitsainen, M.; Linnainmaa, K.: Cytogenetic response to asbestos fibers in cultured human primary mesothelial cells from 10 different donors. Mutat. Res., 1995, 334, 225-233.

10. Fenoglio, I.; Croce, A.; Di Renzo, F.; Tiozzo, R.; Fubini, B. Pure-silica zeolites (Porosils) as model solids for the evaluation of the physicochemical features determining silica toxicity to macrophages. Chem Res. Toxicol. 2000, 13 489-500.

11. Rinaudo, C.; Gastaldi, D.; Belluso, E. Characterization of chrysotile, antigorite and lizardite by FT Raman spectroscopy. Can. Miner. 2003, 41 883-890.

12. Laemmli, U. K.: Cleavage of structural proteins during the assembly of the head of bacteriophage T4. Nature, 1970, 227, 680-685.

13. Shen, H. M.; Shi, C. Y.; Shen, Y.; Ong, C. N.: Detection of elevated reactive oxygen species level in cultured rat hepatocytes treated with aflatoxin B1. Free Radic. Biol. Med., 1996, 21, 139-146.

14. Green, L. C.; Wagner, D. A.; Glogowski, J.; Skipper, P. L.; Wishnok, J. S.; Tannenbaum, S. R:. Analysis of nitrate, nitrite, and $\left[{ }^{15} \mathrm{~N}\right]$ nitrate in biological fluids. Anal. Biochem., 1982, 126, 131-138.

15. Ding, A. H.; Nathan, C. F.; Stuehr, D. J.: Release of reactive nitrogen intermediates and reactive oxygen intermediates from mouse peritoneal macrophages. Comparison of activating cytokines and evidence for independent production. J. Immunol., 1988, 141, 2407-2412.

16. Renis, M.; Cardile, V.; Russo, A.; Campisi, A.; Collova, F.: Glutamine synthetase activity and HSP70 levels in cultured rat astrocytes: effect of 1octadecyl-2-methyl-rac-glycero-3-phosphocholine. Brain Res., 1998, 783, 143-150.

17. Bradford, M. M.: A rapid and sensitive method for the quantitation of microgram quantities of protein utilizing the principle of protein-dye binding. Anal. Biochem., 1976, 72, 248-254.

18. Mosmann, T.: Rapid colorimetric assay for cellular growth and survival: application to proliferation and cytotoxicity assays. J. Immunol. Methods, 1983, 65, 55-63.

19. Mossman, B. T.; Bignon, J.; Corn, M.; Seaton, A.; Gee, J. B.: Asbestos: scientific developments and implications for public policy. Science, 1990, 247, 294-301.

20. Barrett, J. C.: Cellular and molecular mechanisms of asbestos carcinogenicity: implications for biopersistence. Environ. Health Perspect., 1994, 102 Suppl 5, 19-23.

21. Kane, A. B.: Mechanisms of mineral fibre carcinogenesis. IARC Sci. Publ., 1996, 11-34.

22. Vallyathan, V.; Shi, X.: The role of oxygen free radicals in occupational and environmental lung diseases. Environ. Health Perspect. 1997, 105 Suppl 1, 165-177.

23. Kamp, D. W.; Graceffa, P.; Pryor, W. A.; Weitzman, S. A.: The role of free radicals in asbestos-induced diseases. Free Radic. Biol. Med., 1992, 12, 293-315.

24. Hardy, J. A.; Aust, A. E.: The effect of iron binding on the ability of crocidolite asbestos to catalyze DNA singlestrand breaks. Carcinogenesis, 1995, 16, 319-325.

25. Mehrotra, S.; Kakkar, P.; Viswanathan, P. N.: Mitochondrial damage by active oxygen species in vitro. Free Radic. Biol. Med., 1991, 10, 277-285.

26. Fach, E.; Waldman, W. J.; Williams, M.; Long, J.; Meister, R. K.; Dutta, P. K.: Analysis of the biological and chemical reactivity of zeolite-based aluminosilicate fibers and particulates. Environ. Health Perspect., 2002, 110, 1087-1096.

27. Pantopoulos, K.; Weiss, G.; Hentze, M. W.: Nitric oxide and the post-transcriptional control of cellular iron traffic. Trends Cell Biol., 1994, 4, 82-86.

28. Weiss, G.; Werner-Felmayer, G.; Werner, E. R.; Grunewald, K.; Wachter, H.; Hentze, M. W.: Iron 
regulates nitric oxide synthase activity by controlling nuclear transcription. J. Exp. Med., 1994, 180, 969-976.

29. Aldieri, E.; Ghigo, D.; Tomatis, M.; Prandi, L.; Fenoglio, I.; Costamagna, C.; Pescarmona, G.; Bosia, A.; Fubini, B. Iron inhibits the nitric oxide synthesis elicited by asbestos in murine macrophages. Free Radic. Biol. Med., 2001, 31, 412-417.

30. Balazy, M.; Poff, C. D.: Biological nitration of arachidonic acid. Curr. Vasc. Pharmacol., 2004, 2, 81-93.

31. Wong, H. R.; Ryan, M.; Menendez, I. Y.; Denenberg, A.; Wispe, J. R.: Heat shock protein induction protects human respiratory epithelium against nitric oxidemediated cytotoxicity. Shock, 1997, 8, 213-218.

32. Wong, H. R.; Mannix, R. J.; Rusnak, J. M.; Boota, A.; Zar, H.; Watkins, S. C.; Lazo, J. S.; Pitt, B. R.: The heat-shock response attenuates lipopolysaccharide-mediated apoptosis in cultured sheep pulmonary artery endothelial cells. Am. J. Respir. Cell Mol. Biol., 1996, 15, 745-751.

33. Szabo, C.; Wong, H. R.; Salzman, A. L.: Pre-exposure to heat shock inhibits peroxynitrite-induced activation of poly(ADP) ribosyltransferase and protects against peroxynitrite cytotoxicity in $\mathrm{J} 774$ macrophages. Eur. J. Pharmacol., 1996, 315, 221-226.

34. Wang, Y. R.; Xiao, X. Z.; Huang, S. N.; Luo, F. J.; You, J. L.; Luo, H.; Luo, Z. Y.: Heat shock pretreatment prevents hydrogen peroxide injury of pulmonary endothelial cells and macrophages in culture. Shock, 1996, 6, 134-141.

35. Kim, H. P.; Morse, D.; Choi, A. M.: Heat-shock proteins: new keys to the development of cytoprotective therapies. Expert. Opin. Ther. Targets, 2006, 10, 759-769.

36. Kregel, K. C.: Heat shock proteins: modifying factors in physiological stress responses and acquired thermotolerance. J. Appl. Physiol, 2002, 92, 2177 2186.

37. Wheeler, D. S.; Wong, H. R.: Heat shock response and acute lung injury. Free Radic. Biol. Med., 2007, 42 1-14.

38. Njemini, R.; Lambert, M.; Demanet, C.; Mets, T.: Elevated serum heat-shock protein 70 levels in patients with acute infection: use of an optimized enzyme-linked immunosorbent assay. Scand. J. Immunol., 2003, 58, 664-669. 